INTERNATIONAL JOURNAL OF MULTIDISCIPLINARY RESEARCh AND ANALySis

ISSN(print): 2643-9840, ISSN(online): 2643-9875

Volume 04 Issue 06 June 2021

DOI: 10.47191/ijmra/v4-i6-11, Impact Factor: 6.072

Page No.- 748-752

\title{
Factors Related to Low Motivation of Motivation to Carry Baby / Baby to Posyandu
}

\author{
Rahmah Juliani Siregar \\ STIKES Darmais Padang Sidempuan
}

ABSTRACT: Posyandu is a form of community participation in the health sector which is managed by cadres with the target of all members of the community. This study aims to analyze the relationship between factors related to the low motivation of mothers to bring their babies / toddlers to Posyandu Semangka in the IV neighborhood of Siborang Village in 2020.

The research design was an analytic survey using a cross sectional approach. The population in this study were all mothers who had babies / toddlers in the IV environment of Siborang Village, as many as 73 people, with a sample of 73 mothers. The sampling technique was carried out using total sampling. Data analysis used univariate and bivariate tests with Chi Square.

The results showed that the variable of maternal occupation had a significant relationship with the variable of the low motivation of mothers to bring their babies / toddlers to Posyandu with a p-value of $0.004<0.05$; the relationship between the level of education of the mother has a significant relationship with the variable of the low motivation of the mother to bring her baby / toddler to Posyandu with a p-value of $0.011<0.05$; Likewise, the maternal knowledge relationship variable has a significant relationship with the low motivation of the mother to bring her baby / toddler to Posyandu with a p-value of $0.040<0.05$.

It is recommended that the community, especially mothers, be more active in seeking more information about the importance of bringing their babies / toddlers to Posyandu according to the age of the baby / toddler.

KEYWORDS: Knowledge, Motivation, Posyandu

\section{INTRODUCTION}

Posyandu is a form of community participation in the health sector which is managed by cadres with the target of all members of the community. Posyandu has the aim of maintaining and improving the health of mothers, babies, toddlers and couples of childbearing age. Activities at posyandu are real activities that involve community participation in health service efforts from the community and by people who have received education and training from pukesmas regarding basic health services. Initially posyandu received family planning and health services in its development, posyandu can be developed into a forum for communication and services in the community (Runjati, 2010).

In North Sumatra until 2013 the number of posyandu in Indonesia spread across 33 provinces, around 330,000 posyandu units, with 17,750 units in North Sumatra with a target number of children under five as many as 1,571,162 people (North Sumatra Health Department, 2009). The coverage of under-fives weighed in Indonesia in 2014 was $76.8 \%$ with the highest province was West Nusa Tenggara (87.5\%) and the lowest was Papua (30.4\%). Only 2 provinces met the target, namely NTB and West Java (Riskesdas, 2014).

In North Sumatra Province, the number of Posyandu in 2016 was 687 units, but 50 percent of children under five did not carry out regular weighing at Posyandu (Profile of North Sumatra Provincial Health Office, 2018).

Data for the 2018 visits obtained from Puskesmas Padangmatinggi are January 20 people, February 23 people, March 31 people, April 30 people, May 28 people, June 24 people, July 41 people, August 37 people, 24 people in September, 25 people in October, 39 people in November and 20 people in December. So, the average visit for babies / toddlers in 2018 is around 30 people per month. While the target set by the Padangmatinggi Community Health Center is 50 people. (Profile of Padangmatinggi Health Center, 2020).

According to the data obtained at the Semangka Posyandu by the researchers themselves, baby visits to the Semangka Posyandu were very low. Based on the survey and background, researchers are interested in conducting a study entitled "Factors 


\section{Factors Related to Low Motivation of Motivation to Carry Baby / Baby to Posyandu}

Associated with the Low Motivation of Mothers to Bring Their Babies / Toddlers to Posyandu Semangka in Neighborhood IV of Siborang Village in 2021.

Research purposes

The objectives of this research are:

1. To find out the relationship between knowledge and the low motivation of mothers to bring babies / toddlers to the Semangka Posyandu in Neighborhood IV of Siborang Village in 2021.

2. To find out the relationship between age in the family and the low motivation of mothers to bring babies / toddlers to the Watermelon Health Center in Environment IV of Siborang Village in 2021.

3. To find out the relationship between the mother's employment status and the low motivation of the mother to bring babies / toddlers to the Semangka Posyandu in Neighborhood IV of Siborang Village in 2021.

4. To find out the relationship between mother educators and the low motivation of mothers to bring babies / toddlers to the Semangka Posyandu in Neighborhood IV of Siborang Village in 2021.

\section{LITERATURE REVIEW}

\section{Knowledge}

Knowledge (knowledge) is the result of knowing from humans, which simply answers the question "what", for example what is water, what is human, what is nature, and so on. Knowledge can only answer the question of what something is (Notoatmodjo, 2013).

\section{Motivation}

Motivation comes from the Latin word "MOREVE" which means encouragement or driving force. In general, motivation means encouraging to act or act. Meurut Sarwono (2002) "Motivation refers to the process of movement, including encouraging situations that arise from within the individual, the behavior caused by these situations and the goals or ends of movements or actions" (Sunaryo, 2012).

Motivation is a human psychological characteristic that contributes to a person's level of commitment. This includes factors that cause, channel, and maintain human behavior in a certain direction of determination (Stoner \& Freeman, 1995 in Suarli \& Bahtiar, 2012). Motivation according to Purwanto (2012), is anything that encourages someone to do something.

\section{Integrated Healthcare Center}

Posyandu is a health service center for toddlers that is managed and organized for and by the community with technical support from health workers in the context of achieving the Small Prosperous Family Planning Norm (NKKBS) (Syahlan, 2012).

Zulkifli (2013) states that posyandu is a forum to get basic services, especially in the field of health and family planning which is managed by the community, the organizer is carried out by cadres who have been trained in the fields of health and family planning, where the members come from the PKK, community leaders and young women.

According to Effendy (2012) Posyandu is a communication forum, technology transfer and public health services by and for people who have strategic value in developing human resources from an early age.

\section{RESEARCH METHODS}

\section{Types of research}

This type of research is a cross sectional survey, which is a study to study the dynamics of the correlation between risk factors and effects, by way of approaching, observing or collecting data at once (point time approach). That is, each research subject is observed only once and measurements are made of the character status or research subject variables observed at the same time. This cross sectional study is often called transverse research, and is often used in epidemiological studies (Notoatmodjo, 2013).

\section{Location and Time of Research}

The location chosen to be the research site was Posyandu Semangka IV, Siborang Village in 2021.

\section{RESULTS AND DISCUSSION}

The Relationship between Mother's Age and Motivation to Bring Her Baby / Toddler to the Semangka Posyandu in the IV Environment of Siborang Village in 2020 


\section{Factors Related to Low Motivation of Motivation to Carry Baby / Baby to Posyandu}

The results of the Chi Square statistical test show that there is no relationship between age and motivation to bring their babies / toddlers to Posyandu Semangka in Neighborhood IV of Siborang Village. This can be seen from the insignificant value or the $p$-value of $0.757>0.05$.

As stated by Nursalam (2010) it is in accordance with the theory that younger people have a stronger memory and higher creativity in finding and recognizing something that is not yet known compared to older people. In addition, the ability to absorb knowledge only easier to do at a younger age because the brain functions optimally at a young age.

The results of this study are in line with previous research conducted by Ristira R (2014) which shows that from the Chi Square correlation test, the significance value (probability) of 0.300 is more than $0.05(0.300>0.05)$, namely there is no relationship between age and participation of mothers with motivation to bring babies / toddlers to Posyandu in Kemiri District, Purworejo Regency, Central Java. It shows that age does not have a positive relationship with mothers with the motivation to bring their babies / toddlers aged 30-39, higher than that of respondents aged 20-29.

According to researchers, if the younger mother's age will look for and recognize something that is not yet known compared to older people and the ability to absorb new knowledge is easier to do at a younger age to find out about the importance of bringing her baby / toddler to Posyandu, whether it's about goals, benefits, will affect the action of bringing the baby / toddler to Posyandu.

\section{Mother's Work Relationship with Motivation to Bring Her Baby / Toddler to the Semangka Posyandu in the IV Environment of Siborang Village in 2020.}

The results of the Chi Square statistical test show that there is a relationship between work and motivation to bring babies / toddlers to Posyandu Semangka in Neighborhood IV of Siborang Village. This can be seen from the significant value or the $p$ value of $0.004<0.05$.

Based on the theory of work, it describes directly the state of a person's health through the work environment both physically and psychologically (Rothman et al., 2008). work describes a person's socioeconomic status which has an impact on how that person gets access to health services in the context of promotional, preventive and curative efforts. Besides that, work has to do with the motivation to bring babies / toddlers to the posyandu.

Studies on the relationship between work and the motivation to bring their babies / toddlers to posyandu, among others, were conducted by Soewondo and Pramono (2011) which show that in Indonesia most of them are not motivated to bring their babies / toddlers to posyandu are housewives (27.3\%) and entrepreneurs. or service providers (20\%).

According to researchers, if the mother's job does not have strict rules or a job that is self-managed, such as selfemployment, then there is free time and direct opportunity to bring the baby / toddler to the high Posyandu. Regarding the importance of bringing babies / toddlers to Posyandu, whether it's about the purpose, benefits, will affect the action of bringing the baby / toddler to the Posyandu.

\section{Mother's Education Relationship with Motivation to Bring Her Baby / Toddler to the Semangka Posyandu in the IV Environment of Siborang Village in 2020}

The results of the Chi Square statistical test show that there is a relationship between education and motivation to bring babies / toddlers to the Semangka Posyandu in Neighborhood IV of Siborang Village. This can be seen from the significant value or $\mathrm{p}$-value $0.011<0.05$.

Based on Notoatmodjo's theory cited by Sagala (2016), formal education has a very big influence on one's knowledge, if someone is highly educated, they will have high knowledge and vice versa, if someone has low education, they will have low knowledge and will affect understanding something. However, it should be emphasized that someone with low education is not absolutely low-knowledge, nor is knowledge or information that can be obtained not only formally but also informally.

The results of this study are in line with previous research conducted by Ristira R (2014) which shows that from the Chi Square correlation test, a significance value (probability) of 0.003 is less than $0.05(0.003<0.05)$, that is, there is a relationship between education level and maternal participation. with the motivation to bring the baby / toddler to Posyandu in Kemiri District, Purworejo Regency, Central Java. This shows that the level of education has a positive relationship with mothers with the motivation to bring their babies / toddlers with higher education, higher than respondents with secondary and basic education.

According to researchers, if the mother's education is high, it will affect the number of actions of the mother in bringing her baby / toddler to the Posyandu. This can also be influenced by the goals, benefits, advantages and disadvantages of a service at the Posyandu so that it does not have a bad effect on the mother and provides comfort in using it. 


\section{Factors Related to Low Motivation of Motivation to Carry Baby / Baby to Posyandu}

\section{Mother's Knowledge Relationship with Motivation to Bring Her Baby / Toddler to the Semangka Posyandu in the IV Environment of Siborang Village in 2020}

Respondents' knowledge in this study is related to the respondent's understanding and understanding of bringing their babies / toddlers to Posyandu which includes the meaning, purpose and benefits of bringing their babies / toddlers to Posyandu. The results of the analysis of the relationship between maternal knowledge and motivation to bring their babies / toddlers to Posyandu Semangka in Neighborhood IV of Siborang Village with the Chi Square statistical test showed that there was a relationship between knowledge and motivation to bring babies / toddlers to Posyandu. This can be seen from the significant value or $p$-value $0.040<0.05$.

Based on the theory of knowledge is the result of knowing, and this occurs after people sensing a certain object. This sensing occurs through the five human senses, namely the senses of sight, hearing, eyes and ears. Knowledge or cognitive is a very important dominant for the formation of a person's behavior. (Notoatmodjo S, 2013)

This is in accordance with Blum's theory quoted from Notoatmodjo (2013) which states that an individual's actions, including independence and responsibility in behavior, are strongly influenced by dominant cognitive or knowledge. The more real independent act of each individual will be more lasting and lasting if it is based on strong knowledge.

The results of this study are in line with previous research conducted by Elisa (2014) with the title of the relationship between knowledge and attitudes of mothers with motivation to bring their babies / toddlers to Posyandu Tanjung Morawa. The results showed that there was a significant knowledge relationship in the motivation to bring babies / toddlers to Posyandu Tanjung Morawa ( $p=0.002)$.

According to researchers, if the mother's knowledge is good about the importance of bringing her baby / toddler to the Posyandu, whether it's about the objectives, benefits, it will affect the act of bringing the baby / toddler to the Posyandu. This can also be influenced by the advantages and disadvantages of a service at Posyandu so that it does not have a bad effect on the mother and provides comfort in using it.

\section{CONCLUSIONS}

Based on the research results, it can be concluded as follows:

1. There is no relationship between the mother's age and the motivation to bring the baby / toddler to Posyandu Semangka in Neighborhood IV of Siborang Village, namely the value is not significant or the $p$-value is 0.575>0.05.

2. There is a relationship between the mother's work and the motivation to bring the baby / toddler to Posyandu Semangka in Neighborhood IV of Siborang Village, which is a significant value or a p-value of $0.004<0.05$.

3. There is a relationship between maternal education and motivation to bring babies / toddlers to Posyandu Semangka in the neighborhood of Siborang Village, which is a significant value or $p$-value $0.011<0.05$.

4. There is a relationship between maternal knowledge and motivation to bring their babies / toddlers to Posyandu Semangka in Neighborhood IV of Siborang Village, which is a significant value or p-value $0.040<0.05$.

\section{BIBLIOGRAPHY}

1) Arikunto.Suharsini. 2010. Research Procedure A Practical Approach. Revised edition VI.Rineka Cipta: Jakarta.

2) Anggraeni, D. Y, and Sutomo, B. 2010. Healthy Food Complementary to Breastfeeding. PT. Agromedia Pustaka: Jakarta.

3) Ajunk. 2009. Diet for Children and Adolescents. Gramedia Pustaka Utama: Jakarta.

4) Choirunnisa, 2009. The Effect of Using lodized Salt on the Nutritional Status of Short Toddlers in Amuntai Tengah Subdistrict, Hulu-Sungai Utara Regency, 2010. Thesis. Stikes Husada Borneo: Banjarbaru.

5) Effendy. 2012. Basics of Public Health Nursing. EGC: Jakarta.

6) Hidayat, A. 2014. Nursing Research Methods and Data Analysis Techniques. Salemba Medika .: Jakarta.

7) Ismawati, C. 2010. Posyandu and Desa Siaga a guide for midwives and cadres. Nura Medika: Yogyakarta.

8) RI Ministry of Health. 2014. Basic Health Research. Balitbang:. Jakarta.

9) Langgulung, Hasan. 2016. Humans and Education An Educational Psychological Analysis. Pustaka Al-Husna: Jakarta

10) Mahfoedz, Ichram. 2009. Research Methods in Health, Nursing, Midwifery, Medicine.Fitrimaya: Yogyakarta

11) Mubarak, WI. 2012. Public Health Sciences. Salemba Medika: Jakarta=

12) Mubarak, WI. 2012. Health Promotion An Introduction to Teaching and Learning in Education. Graha Science: Yogyakarta

13) Notoatmodjo, S. 2013. Public Health Sciences. PT Rineka Cipta: Jakarta

14) Notoatmodjo, S. 2013. Health Promotion and Science Behavior. PT Rineka Cipta: Jakarta.

15) Notoatmodjo, S. 2013. Health Research Methods. Rev. Edition. PT Rinka: Cipta Jakarta 


\section{Factors Related to Low Motivation of Motivation to Carry Baby / Baby to Posyandu}

16) Nursalam. 2010. Concept and Application of Nursing Research Methodology. Salemba Medika: Jakarta

17) Health Profile of North Sumatra. 2018. Health and Social Welfare Office. From the website http: //profil.dinkes.kkes.sumut. Retrieved June 3, 2019.

18) Purwanto.2012. Educational Psychology. Youth Rosda work: Bandung

19) Puskesmas Padangmatinggi Puskesmas Ulumahuam. 2019. Profile of Puskesmas Padangmatinggi, Padangsidimpuan

20) Riskesdas. 2014. Weighted Toddler Coverage in Indonesia. Jakarta: Balitbang

21) Ristira R. 2014. The Relationship Between Mother's Education and Knowledge Level with the motivation to bring her baby / toddler to Posyandu in Kemiri District, Purworejo Regency, Central Java. Muhammadiyah University of Surakarta [ejournal]. 2014; 1-15. Available at: http://eprints.ums.ac.id/29233/9/10_naskah_publikasi.pdf

22) Rothman et al., 2008. Communication for Health and Behavior Change. Gadjah Mada University Press: Yogyakarta

23) Runjati. 2010. Community Midwifery Care. EGC: Jakarta

24) Rusni. 2012. Factors Associated with the Frequency of Visits of Mothers with Toddlers to the Posyandu, Lewet Village, Amurang Timur District, South Minahasa Regency. JIDAN Midwife Scientific Journal. Volume 1 Number 1

25) Sagala, K. H. 2016. Factors Affecting Visits of Toddlers in Utilizing Posyandu in Sei Rotan Village, Percut Sei Tuan District, Bandar Khalip Public Health Center Work Area (Thesis). Medan: Faculty of Public Health, University of North Sumatra.

26) Sarwono, S. W. 2012. Psychology of adolescents. Revised edition 8. Raja Grafindo Pustaka: Jakarta

27) Soetjiningsih. 2011. Child Development. Graha IImu: Yogjakarta.

28) Soewondo, Pramono. 2011. Prevalence, Characteristics, and Predictor of Prediabetes in Indonesia. Medical Journal Indonesia Vol 20 No 4 November 2011

29) Suarlidan Bahtiar 2012. Nursing Management With a Practical Approach. Erlangga: Jakarta.

30) Sudirman. 2017. The Relationship between Mother's Knowledge in Utilizing the Posyandu Program with the Nutritional Status of Toddlers at Posyandu Bougenville, Cimahi Selatan City. Kartika Health Journal. Volume 12 Number 2

31) Sunaryo. 2012. Gerontic Nursing Care. CV Andi Offset: Yogyakarta

32) Supartini. 2014. Textbook of basic concepts of child nursing. EGC: Jakarta.

33) Syahlan J.H. 2012. Community Midwifery. Jakarta: Balai Pustaka.

34) Taufik. 2017.Pediatric Education. Open University: Jakarta

35) Birthday. 2012. The Relationship of Family Activity in Posyandu Activities with the Nutritional Status of Toddlers in Rancaeke Kulon Village, Rancaekek District, Thesis, Padjadjaran University, Bandung.

36) WHO. 2014. Infant Mortality Rate. World Health Organization. From the website http://www.who.int/child.adolescent.health/data/media/cah.chp.myanmar.pdf. Accessed on 6 July 2019.

37) Zulkifli. 2013. Posyandu and Health Cadres. FKM-USU. Field 